\title{
Temporary Works Design and Construction Ergonomics
}

John Smallwood

\begin{abstract}
Temporary works designers influence construction ergonomics directly and indirectly. The direct influence is because of design, details, and method of connecting, and depending upon the type of procurement system, supervisory, and administrative interventions. The indirect influence is because of the type of procurement system used, prequalification, project duration, partnering, and the facilitating of pre-planning.

A questionnaire survey was administered among attendees attending an inhouse support work designer and supplier 'designing for construction ergonomics' workshop.

The following constitute the salient findings. Quality, is more important to the respondents' organisation than construction ergonomics, and project health and safety (H\&S). A range of temporary works design related aspects impact on construction ergonomics, and the respondents' organisation considers / refers to such aspects frequently, and on a range of design, procurement, and construction occasions. Experience predominates in terms of how ergonomics knowledge was acquired. A range of aspects and interventions have the potential to contribute to an improvement in construction ergonomics.

The paper concludes that respondents contribute to construction ergonomics, but there is potential for enhanced contributions.

Recommendations include that tertiary-built environment education should address temporary works design and construction $\mathrm{H} \& S$ and ergonomics, temporary works design standards should highlight designing for construction H\&S and ergonomics, and practice notes, and continuing professional development (CPD) should be evolved.
\end{abstract} works

Keywords - construction, design, ergonomics, temporary

\section{Introduction}

The definition of 'designer' in the South African Construction Regulations [1] includes, inter alia, a competent person who designs temporary work, including its components. According to the South African Construction Regulations [1], designers must take cognisance of ergonomic design principles during the design stage to minimise ergonomic related hazards in all phases of the life cycle of a structure. This alludes to the term 'designing for safety', which Behm [2] defines as "The consideration of construction site safety in the preparation of plans and specifications for construction projects." Thorpe [3] in turn contends that design is an important stage of projects, as it is at this stage that conceptual ideas are ideally converted into constructable realities. Furthermore, 'designing for $H \& S$ ' is one of the designing for constructability principles. Thorpe [3] further states that designing for safety is one of a range of considerations that need to be balanced simultaneously during design.
The Construction Regulations and international literature highlight the relevance of designing for H\&S and ergonomics, which resulted in a study that was conducted among staff of a major multinational temporary works designer and supplier, the objectives being to determine relative to their organisation:

- Importance of project parameters;

- Importance of ergonomics during seven temporary works stages of projects;

- Extent to which construction ergonomics could be influenced during seven temporary works stages of projects;

- Frequency at which construction ergonomics is considered on various occasions and relative to various temporary works design related aspects;

- Extent to which various temporary works design related aspects impact on construction ergonomics;

- $\quad$ Source of ergonomics knowledge;

- Potential of various aspects / interventions to contribute to an improvement in construction ergonomics during various project (overall) stages, and

- Degree of awareness relative to the ergonomics provisions of the Construction Regulations, and the extent they have influenced consideration of construction ergonomics.

\section{Review of the Literature}

\section{A. Health and Safety legislation and recommendations pertaining to designers}

Prior to the promulgation of the Construction Regulations, all designers were required to address $H \& S$, as in terms of Section 10 of the Occupational H\&S Act [4] designers are allocated the responsibility to ensure that any 'article' is safe and without risks when properly used. This includes buildings and structures. In terms of the South African Construction Regulations [1], clients and designers, including temporary works designers, have responsibilities with respect to construction H\&S and ergonomics.

Clients are required to, inter alia, prepare an H\&S specification based on their baseline risk assessment (BRA), which is then provided to designers. They must then ensure that the designer takes the H\&S specification into account during design, and that the designers carry out their duties in terms of Regulation 6 'Duties of designers'. Thereafter, 
clients must include the $H \& S$ specification in the tender documentation, which in theory should have been revised to include any relevant $\mathrm{H} \& \mathrm{~S}$ information included in the designer report as discussed below.

Designers in turn are required to, inter alia: consider the H\&S specification; submit a report to the client before tender stage that includes all the relevant H\&S information about the design that may affect the pricing of the work, the geotechnical-science aspects, and the loading that the structure is designed to withstand; inform the client of any known or anticipated dangers or hazards relating to the construction work, and make available all relevant information required for the safe execution of the work upon being designed or when the design is changed; modify the design or make use of substitute materials where the design necessitates the use of dangerous procedures or materials hazardous to $H \& S$, and consider hazards relating to subsequent maintenance of the structure and make provision in the design for that work to be performed to minimize the risk. To mitigate design originated hazards, requires hazard identification and risk assessment (HIRA) and appropriate responses, which process should be structured and documented.

In terms of the Draft Ergonomics Regulations [5] '5.1 Designers of machinery, equipment or articles for use at work, must: eliminate ergonomic risk factors from the design, or where this is not reasonably practicable, must minimise the ergonomic risk factors that workers may be exposed to in each possible use of the items; provide information regarding the ergonomic risk factors identified and the controls to the manufacturer, so that the manufacturer may take action where reasonably practicable to eliminate or minimise residual ergonomic risk factors, and provide information to the manufacturer for potential users involved in each phase of the lifecycle regarding the ergonomic risk factors that he / she could not eliminate, and the conditions for safe use. Although these are draft regulations, they are not onerous, and merely require design HIRAs, and appropriate responses.

Furthermore, the International Labour Office (ILO) [6] as early as 1992 recommended that designers should: receive training in $\mathrm{H} \& \mathrm{~S}$; integrate the $\mathrm{H} \& \mathrm{~S}$ of construction workers into the design and planning process, and not include anything in a design which would necessitate the use of dangerous structural or other procedures or hazardous materials which could be avoided by design modifications or by substitute materials.

\section{Research}

A questionnaire survey was administered among staff of a major international temporary works designer and supplier attending an in house 'designing for construction ergonomics' workshop presented by the author.

A previous study conducted among engineers in South Africa to determine their perceptions and practices with respect to construction $H \& S$ investigated the: frequency at which construction $\mathrm{H} \& \mathrm{~S}$ is considered on various occasions and relative to various design related aspects; extent to which various design related aspects impact on construction H\&S; source of H\&S knowledge, and the potential of various aspects to contribute to an improvement in construction H\&S [7]. The study reported on constitutes a replication of this prior study, which study in turn constitutes the origin of the occasions, aspects, and sources.

Table 1 indicates the importance of six project parameters to respondents' orgnisations in terms of a mean score (MS) ranging between 1.00 and 5.00 , based upon percentage responses to a scale of 1 (not important) to 5 (very important). It is notable that the MSs are all above the midpoint of 3.00, which indicates that in general the respondents can be deemed to perceive the parameters as important to their organisation. However, given that the MSs for all the parameters are $>4.20$ $\leq 5.00$, the respondents can be deemed to perceive them to be between more than important to very important / very important. It is notable that only two of the three traditional project parameters, namely project quality, and project time are ranked within the top three, and the subject of the study, construction ergonomics, is ranked second.

TABLE I. IMPORTANCE OF PROJECT PARAMETERS TO RESPONDENTS' ORGANISATIONS.

\begin{tabular}{|l|c|c|}
\hline Parameter & MS & Rank \\
\hline Project quality & 4.78 & 1 \\
\hline Construction ergonomics & 4.75 & 2 \\
\hline Project time & 4.74 & 3 \\
\hline Project cost & 4.67 & 4 \\
\hline Project health and safety (H\&S) & 4.61 & 5 \\
\hline Environment & 4.26 & 6 \\
\hline
\end{tabular}

Table 2 indicates the importance of ergonomics to respondents' organisations during seven temporary works stages of projects in terms of a MS ranging between 1.00 and 5.00 , based upon percentage responses to a scale of 1 (not important) to 5 (very important). It is notable that the MSs are all above the midpoint of 3.00, which indicates that in general the respondents can be deemed to perceive the parameters as important to their organisation. However, given that the MSs for all the parameters are $>4.20 \leq 5.00$, the respondents can be deemed to perceive them to be between more than important to very important / very important. It is notable that supply of equipment is ranked first and detailed design (Stage 3) second. Concept and feasibility (Stage 2), and project initiation and briefing (Stage 1) are ranked third and fourth respectively.

TABLE 2. IMPORTANCE OF ERGONOMICS TO RESPONDENTS' ORGANISATIONS DURING SEVEN TEMPORARY WORKS STAGES OF PROJECTS.

\begin{tabular}{|l|c|c|}
\hline Stage & MS & Rank \\
\hline Supply of equipment & 4.62 & 1 \\
\hline Detailed design & 4.55 & 2 \\
\hline Concept and feasibility & 4.50 & 3 \\
\hline Project initiation and briefing & 4.47 & 4 \\
\hline $\begin{array}{l}\text { Construction documentation and } \\
\text { management }\end{array}$ & 4.33 & 5 \\
\hline Project close out & 4.30 & 6 \\
\hline Tender documentation and procurement & 4.25 & 7 \\
\hline
\end{tabular}

Table 3 indicates the extent to which the respondents' organisation could influence construction ergonomics during seven temporary works stages of projects in terms of a MS 
ranging between 1.00 and 5.00 , based upon percentage responses to a scale of 1 (minor) to 5 (major). It is notable that the MSs are all above the midpoint of 3.00, which indicates that in general the respondents can be deemed to perceive the extent to which the respondents' organisation could influence construction ergonomics during seven temporary works stages of projects to be major as opposed to minor. However, given that the MSs for $3 / 7(42.9 \%)$ stages are $>4.20 \leq 5.00$, the respondents can be deemed to perceive the extent to be between a near major to major / major extent. It is notable that detailed design (Stage 3), and supply of equipment predominate followed by concept and feasibility (Stage 2). The remaining 4 / 7 (57.1\%) MSs are $>3.40 \leq 4.20$ - between some extent to a near major extent / near major extent.

TABLE 3. EXTENT TO WHICH THE RESPONDENTS' ORGANISATION COULD INFLUENCE CONSTRUCTION ERGONOMICS DURING SEVEN TEMPORARY WORKS STAGES OF PROJECTS.

\begin{tabular}{|l|c|c|}
\hline Stage & MS & Rank \\
\hline Detailed design & 4.68 & 1 \\
\hline Supply of equipment & 4.45 & 2 \\
\hline Concept and feasibility & 4.27 & 3 \\
\hline $\begin{array}{l}\text { Construction documentation and } \\
\text { management }\end{array}$ & 3.90 & 4 \\
\hline Project close out & 3.89 & 5 \\
\hline Project initiation and briefing & 3.76 & 6 \\
\hline Tender documentation and procurement & 3.60 & 7 \\
\hline
\end{tabular}

Table 4 presents the frequency at which the respondents' organisation considers or refers to construction ergonomics on fourteen occasions in terms of a MS ranging between 1.00 and 5.00 , based upon percentage responses to a frequency range, never to always. It is notable that all the MSs are above the midpoint of the range, namely 3.00 , which indicates the consideration of or reference to construction ergonomics on these occasions can be deemed to be prevalent.

It is notable that 6 / $14(42.9 \%)$ occasions have MSs $>4.20 \leq$ 5.00 - between often to always / always. 3 are upstream, 1 is midstream, 1 is downstream, and 1 is triple-stream. $7 / 14$ $(50 \%)$ of the occasions have MSs $>3.40 \leq 4.20$ - between sometimes to often / often. 3 are 'upstream', 1 is 'midstream', 2 are 'downstream', and 1 is triple-stream. Only one MSs is > $2.60 \leq 3.40$ - between rarely to sometimes / sometimes, namely discussion of $\mathrm{H} \& \mathrm{~S}$ plan, which is midstream.

Table 5 presents the frequency at which the respondents' organisation considers / refers to construction ergonomics relative to fifteen temporary works design related aspects, in terms of a MS ranging between 1.00 and 5.00, based upon percentage responses to a frequency range, never to always. It is notable that all the MSs are above the midpoint of 3.00, which indicates consideration of / reference to $H \& S$ relative to these temporary works design related aspects can be deemed to be prevalent.

It is notable that 5 / 15 (33.3\%) MSs fall within the range > $4.20 \leq 5.00$ - between often to always / always, and 9 / 15 $(60 \%)$ MSs are $>3.40 \leq 4.20$ - between sometimes to often / often. The remaining MS, which is virtually in the upper range, is $>2.60 \leq 3.40$ - between rarely to sometimes / sometimes.

TABLE 4. FREQUENCY AT WHICH THE RESPONDENTS' ORGANISATION CONSIDERS / REFERS TO CONSTRUCTION ERGONOMICS ON VARIOUS OCCASIONS.

\begin{tabular}{|l|c|c|}
\hline Occasion & MS & Rank \\
\hline Design (U) & 4.68 & 1 \\
\hline Detailed design (U) & 4.59 & 2 \\
\hline $\begin{array}{l}\text { Discussions with the principal } \\
\text { contractor (U, M, D) }\end{array}$ & 4.45 & 3 \\
\hline Site visits / inspections (D) & 4.41 & 4 \\
\hline Working drawings (U) & 4.32 & 5 \\
\hline Equipment delivery (M) & 4.29 & 6 \\
\hline Client (Contractor) meetings (U, M, D) & 4.19 & 7 \\
\hline Project progress meetings (D) & 4.00 & 8 \\
\hline Design coordination meetings (U) & 4.00 & 9 \\
\hline Project close out reports (D) & 3.88 & 10 \\
\hline Deliberating project duration (U) & 3.86 & 11 \\
\hline Preparing project documentation (M) & 3.68 & 12 \\
\hline Constructability reviews (U) & 3.56 & 13 \\
\hline Discussion of H\&S plan (M) & 3.33 & 14 \\
\hline
\end{tabular}

Table 5 presents the frequency at which the respondents' organisation considers / refers to construction ergonomics relative to fifteen temporary works design related aspects, in terms of a MS ranging between 1.00 and 5.00, based upon percentage responses to a frequency range, never to always. It is notable that all the MSs are above the midpoint of 3.00 , which indicates consideration of / reference to $\mathrm{H} \& S$ relative to these temporary works design related aspects can be deemed to be prevalent.

It is notable that $5 / 15(33.3 \%)$ MSs fall within the range > $4.20 \leq 5.00$ - between often to always / always, and $9 / 15$ $(60 \%)$ MSs are $>3.40 \leq 4.20$ - between sometimes to often / often. The remaining MS, which is virtually in the upper range, is $>2.60 \leq 3.40$ - between rarely to sometimes / sometimes.

The top six ranked occasions predominate, namely method of connecting, method of fixing, details, specification, mass of components, and design of temporary works (general).

TABLE 5. FREQUENCY AT WHICH THE RESPONDENTS' ORGANISATION CONSIDERS / REFERS TO CONSTRUCTION ERGONOMICS RELATIVE TO VARIOUS TEMPORARY WORKS DESIGN RELATED ASPECTS.

\begin{tabular}{|l|c|c|}
\hline Aspect & MS & Rank \\
\hline Method of connecting & 4.33 & 1 \\
\hline Method of fixing & 4.33 & 2 \\
\hline Details & 4.32 & 3 \\
\hline Specification & 4.24 & 4 \\
\hline Mass of components & 4.24 & 5 \\
\hline Design of temporary works (general) & 4.19 & 6 \\
\hline Surface area of components & 4.05 & 7 \\
\hline Finish of components & 4.05 & 8 \\
\hline Elevations & 4.00 & 9 \\
\hline Position of components & 4.00 & 10 \\
\hline Plan layout & 4.00 & 11 \\
\hline Sectional area of components & 3.95 & 12 \\
\hline Site location & 3.71 & 13 \\
\hline Edge (s) of components & 3.63 & 14 \\
\hline Texture of components & 3.39 & 15 \\
\hline
\end{tabular}


Table 6 indicates the perceived impact of fifteen temporary works design related aspects on construction ergonomics, in terms of percentage responses to 'does not' and a scale of 1 (minor) to 5 (major), and a MS ranging between 0.00 and 5.00. Given that a 'does not' option was provided the scale effectively consists of six points, and hence the MS range. It is notable that all fifteen MSs are above the midpoint of 2.50, which indicates the respondents perceive the design related aspects to impact on construction ergonomics.

It is notable that $7 / 15(46.7 \%)$ MSs are $>4.17 \leq 5.00$ between a near major to major impact / major impact. The remaining $8 / 15(53.3 \%)$ aspects' MSs are $>3.34 \leq 4.17$, which indicates that they have between an impact and a near major impact / near major impact on construction ergonomics.

It is not notable that details ranked first, is ranked third in terms of consideration / reference, and method of connecting, and method of fixing ranked second and third respectively, are ranked first and second in terms of consideration / reference respectively. Specification ranked fourth, is also ranked fourth in terms of consideration / reference.

TABLE 6. EXTENT TO WHICH VARIOUS TEMPORARY WORKS DESIGN RELATED ASPECTS IMPACT ON CONSTRUCTION ERGONOMICS.

\begin{tabular}{|l|c|c|}
\hline Aspect & MS & Rank \\
\hline Details & 4.45 & 1 \\
\hline Method of connecting & 4.43 & 2 \\
\hline Method of fixing & 4.43 & 3 \\
\hline Specification & 4.29 & 4 \\
\hline Plan layout & 4.27 & 5 \\
\hline Design of temporary works (general) & 4.27 & 6 \\
\hline Mass of components & 4.23 & 7 \\
\hline Elevations & 4.14 & 8 \\
\hline Surface area of components & 3.85 & 9 \\
\hline Finish of components & 3.75 & 10 \\
\hline Site location & 3.71 & 11 \\
\hline Position of components & 3.65 & 12 \\
\hline Sectional area of components & 3.58 & 13 \\
\hline Edge (s) of components & 3.56 & 14 \\
\hline Texture of components & 3.43 & 15 \\
\hline
\end{tabular}

Table 7 indicates the respondents' self-rating of their knowledge of ergonomics, construction ergonomics, and 'designing for ergonomics' skills in terms of a MS ranging between 1.00 and 5.00, based upon percentage responses to a scale of 1 (limited) to 5 (extensive). Given that the MSs are $\leq$ 3.00 , the knowledge can be deemed to be more limited than extensive. However, all three MSs are $>2.60 \leq 3.40-$ less than average to average / average.

TABLE 7. RESPONDENTS' SELF-RATING OF THEIR KNOWLEDGE WITH RESPECT TO ASPECTS.

\begin{tabular}{|l|c|c|}
\hline Aspect & MS & Rank \\
\hline Ergonomics & 2.77 & 1 \\
\hline Designing for construction ergonomics & 2.77 & 2 \\
\hline Construction ergonomics & 2.73 & 3 \\
\hline
\end{tabular}

Table 8 indicates the potential of various aspects / interventions to contribute to an improvement in construction rgonomics during the various project (overall) phases in terms of percentage responses to a scale of 1 (minor) to 5 (major), and a MS ranging between 1.00 and 5.00. The letters inserted within parentheses denote whether the aspect / intervention is construction (C), design (D), procurement $(\mathrm{P})$, or multi-phase related. It is notable that all the MSs are above the midpoint of 3.00, which indicates that in general the respondents can be deemed to perceive the various aspects / interventions to have the potential to contribute to an improvement in construction ergonomics during the various project (overall) phases.

$7 / 15(46.7 \%)$ MSs are $>4.20 \leq 5.00$ - between near major potential to major potential / major potential to contribute. Design of equipment (construction) predominates. It is notable that the top ranked aspect / intervention is construction phase related. Three of the top seven are construction related, three are design related, and one is design and construction related. The remaining $8 / 15(53.3 \%)$ of the aspects / interventions are $>3.40 \leq 4.20$ - between potential to near major potential / near major potential to contribute.

TABLE 8. POTENTIAL OF VARIOUS ASPECTS / INTERVENTIONS TO CONTRIBUTE TO AN IMPROVEMENT IN CONSTRUCTION ERGONOMICS DURING THE VARIOUS PROJECT (OVERALL) PHASES.

\begin{tabular}{|l|c|c|}
\hline Occasion & MS & Rank \\
\hline Design of equipment (construction) (C) & 4.62 & 1 \\
\hline Details (D) & 4.36 & 2 \\
\hline Contractor planning (C) & 4.35 & 3 \\
\hline Mechanisation (D \& C) & 4.33 & 4 \\
\hline General design (D) & 4.32 & 5 \\
\hline Safe work procedures (C) & 4.29 & 6 \\
\hline Constructability (general) (D) & 4.24 & 7 \\
\hline Re-engineering of design (D) & 4.19 & 8 \\
\hline Specification (D) & 4.15 & 9 \\
\hline Design of tools (C) & 4.15 & 10 \\
\hline Re-engineering of construction (C) & 4.14 & 11 \\
\hline Awareness (D \& C) & 4.10 & 12 \\
\hline Prefabrication (D) & 4.10 & 13 \\
\hline Hazard identification and risk (D \& C) & 4.00 & 14 \\
\hline Workshops on site (C) & 3.95 & 15 \\
\hline
\end{tabular}

Table 9 indicates the respondents' source of ergonomics knowledge. Experience predominates (39.1\%), followed by workshops $(26.1 \%)$, tertiary education $(17.4 \%)$, magazine articles (13.1\%), and other (13.1\%). Only $4.1 \%$ identified postgraduate qualifications.

TABLE 9. EXTENT TO WHICH THE RESPONDENTS' ORGANISATION COULD INFLUENCE CONSTRUCTION ERGONOMICS DURING SEVEN TEMPORARY WORKS STAGES OF PROJECTS.

\begin{tabular}{|l|c|}
\hline Source & $\mathbf{\%}$ \\
\hline Experience & 39.1 \\
\hline Workshops & 26.1 \\
\hline Tertiary education & 17.4 \\
\hline Magazine articles & 13.1 \\
\hline Other & 13.1 \\
\hline Post graduate qualifications & 4.1 \\
\hline Conference papers & 0.0 \\
\hline CPD seminars & 0.0 \\
\hline Journal Papers & 0.0 \\
\hline Practice notes & 0.0 \\
\hline
\end{tabular}

Respondents were required to indicate the extent to which the Construction Regulations have influenced their 
consideration of construction ergonomics, in terms of percentage responses to 'have not' and a scale of 1 (minor) to 5 (major), and a MS ranging between 0.00 and 5.00. Given that a 'have not' option was provided, the scale effectively consists of six points, and hence the MS range. It is notable that the MS is above the midpoint of 2.50 , which indicates the extent is more major than minor. However, in terms of ranges, the MS of 3.33 falls within the range $>2.50 \leq 3.33$, which indicates that the extent is between a near minor extent to some extent / some extent. It should be noted that 3.33 is just below the upper range $>3.34 \leq 4.17$, which indicates between some extent and a near major extent / near major extent.

\section{Conclusions}

The traditional project parameter of quality is more important than construction ergonomics, cost, time, $H \& S$ and environment to the respondents' organisation, and with the exception of the environment there are no major variances between the respective MSs - there is a difference of 0.17 between first ranked quality and fifth ranked H\&S. Therefore, it can be concluded that the respondents' organisation understands and appreciates the synergy between construction ergonomics and H\&S, and the other parameters.

Construction ergonomics is more important during the supply of equipment, detailed design, concept and feasibility, and project initiation and briefing temporary works stages of projects, than the midstream and downstream stages of construction documentation and management, project close out, and tender documentation and procurement. Therefore, it can be concluded that the respondents' organisation understands and appreciates that ergonomics can be influenced more during the upstream than downstream stages. This is underscored by the extent the respondents' organisation could influence construction ergonomics during the detailed design, supply of equipment, and concept and feasibility temporary works stages of projects.

The respondents' organisation does consider construction ergonomics on various occasions, however, more so during upstream phases than mid-stream phases, design (upstream), detailed design (upstream), and discussions with the principal contractor (upstream, midstream, downstream). Therefore, it can be concluded that the cited importance thereof does manifest itself. Furthermore, the MSs relative to the top $6 / 14$ $(42.9 \%)$ indicate a frequency of often to always / always.

The respondents' organisation considers / refer to construction ergonomics relative to fifteen temporary works design related aspects. The top five $(33.3 \%)$ aspects, namely method of connecting, method of fixing, details, specification, and mass of components, have MSs, which indicate a frequency of often to always / always. The frequency relative to mass of components is notable due to the manual handling of components, and relative to the other aspects, which impact on construction ergonomics.

Respondents do appreciate the extent to which various temporary works design related aspects impact on construction ergonomics in that they maintain 7 / 15 (46.7\%) aspects have between a near major to major impact / major impact, and 8 /
$15(53.3 \%)$ an impact to near major impact / near major impact thereon.

Furthermore, given the convergent rankings between the perceived impact of temporary works design related aspects on construction ergonomics, and the consideration / reference to such aspects, it can be concluded that respondents' actions reflect rational thinking, and are likely to be based on a structured process such as documented design hazard identification and risk assessment.

Given the sources of respondents' ergonomics knowledge it can be concluded that the sources are more informal than formal - experience $(39.1 \%)$, and workshops (26.1\%), vis-àvis tertiary education $(17.4 \%)$. It can also be concluded that tertiary built environment education and the related professions are not addressing ergonomics to the extent that they should. These conclusions are reinforced by the respondents' 'below average' self-rating of their knowledge of 'ergonomics', 'designing for construction ergonomics', and 'construction ergonomics' skills.

Given the perceived potential of various aspects / interventions to contribute to an improvement in construction ergonomics, it can be concluded that respondents do appreciate the potential of various design, procurement and construction practices to contribute to an improvement in construction ergonomics.

\section{v.Recommendations}

Tertiary built environment education should address temporary works design and construction H\&S and ergonomics, and highlight the role thereof in overall project performance. Furthermore, designing for construction H\&S and ergonomics, temporary works design included, should be introduced and more importantly, embedded in tertiary built environment education programmes.

Temporary works design standards should highlight designing for construction $\mathrm{H} \& \mathrm{~S}$ and ergonomics, and practice notes, and continuing professional development (CPD) should be evolved. The Ergonomics Regulations should be promulgated the soonest.

\section{References}

[1] Republic of South Africa, No. R. 84 Occupational Health and Safety Act, 1993 Construction Regulations 2014. Government Gazette No. 37305. Pretoria, 2014.

[2] M. Behm, An Analysis of Construction Accidents from a Design Perspective, Silver Spring: The Center to Protect Workers' Rights, 2006.

[3] B. Thorpe, Health and Safety in Construction Design, Aldershot: Gower Publishing Limited, 2006.

[4] Republic of South Africa, Government Gazette No. 14918. Occupational Health \& Safety Act: No. 85 of 1993. Pretoria, 1993.

[5] Republic of South Africa, Draft Ergonomics Regulations No. 40578, Pretoria, 2017.

[6] International Labour Office (ILO), Safety and health in construction, ILO, Geneva, 1992.

[7] J.J. Smallwood, The influence of engineering designers on health and safety during construction, Journal of the South African Institution of Civil Engineering, vol. 46, no. 1, pp. 2-8, 2004. 